\title{
Kanon in die kanon
}

\author{
P M Venter \\ Departement Ou-Testamentiese Wetenskap \\ Universiteit van Pretoria.
}

\begin{abstract}
Canon in the canon

The reductionist trend of the notion of a canon in the canon is radically changed in a postmodern era. A modernist hegemonic notion of canon shifted towards a contextually based inter subjective dialogue between reader and text. Canon criticism shifted the focus of attention from the text towards the process in which the text operates as canon. Issues in this process are the actions of discrimination and of formal selection. These should be seen as the canon in the canon process. Such a view is not reductionist, but rather pluralistic. Canon in the canon can no longer be a reductionist and static choice from Biblical materials, but is a dynamic and ongoing process of endless combinations, even of contradictory passages, to meet the demands of each new situation.
\end{abstract}

\section{1. 'N HERDEFINISIE VAN DIE BEGRIP KANON-IN-DIE- KANON?}

Elke poging om die teologie van die Ou Testament/Nuwe Testament weer te gee, is reduserend van aard. Dit neig altyd na een of ander kerngedagte. Brueggemann (1997: 82) skryf hierdie tendens aan die Aristoteliese logika toe wat steeds die botoon gevoer het in die tradisionele Westerse teologie.

Wanneer die kanonbegrip in die soeke na die teologie van die Testamente ingesluit word, word daardie teologie as die kanon-in-die kanon beskou. In die groot geheel van kanonieke Bybelse boeke word een of ander idee (soos verbond), of uitgebreide skema (soos die Dekaloog) of selfs 'n hele boek (Deuteronomium) as die kern van die geheel beskou. Dit is die teologiese kern van die kanon, die kanon in die kanon.

Op die gebied van die Ou-Testamentiese teologie het die tendens om die teologie daarvan deur reduksie te vind sedert Von Rad se soeke na 'n kerugmatiese maksimum en 
die bewuswording van die teologiese pluriformiteit van die Ou Testament, al meer in diskrediet begin raak. Die soeke het begin na 'n nie-reduktiewe manier om die teologie daarvan te beskryf. Die ontdekking van die Dooie Seerolle en die ontwikkeling van die nuwe dissipline van kanonkritiek van Childs en Sanders het eweneens ingrypende veranderings in die kanonbegrip teweeggebring. As daar met ' $n$ kanon-in-die-kanon gewerk word, moet hierdie veranderings verdiskonteer word. Hierdie artikel ondersoek die veranderings wat hierdie tendense in die nosie van kanon-in-die-kanon meegebring het.

\section{DIE KANON IN DIE KANON BY G M M PELSER}

G M M Pelser is 'n eksponent van die kanon-in-die kanon gedagte. As huldiging van professor Pelser by sy emeritaatsaanvaarding begin ek by die inhoud wat hy aan die nosie van kanon-in-die-kanon gee as aansluitingspunt om die saak aan die orde te stel. Alhoewel hy slegs een artikel aan die einde van die tagtigerjare van die vorige eeu oor hierdie onderwerp gepubliseer het, is hy alom bekend as vurige pleitbesorger vir hierdie benadering.

Pelser se vertrekpunt is die gegewene van 'n verskeidenheid van teologiese standpunte, of teologieë, in die kanon. Op grond van die historiese karakter van die Nuwe Testament en die prinsipiële oortuiging dat die Bybel nie de jure afgesluit is nie, kan dit vir hom nie betwyfel word nie "... dat dit teologies eenvoudig onmoontlik is om al die verskillende teologieë in die Nuwe Testament (en ewe seer in die Ou Testament) met mekaar te harmoniseer of op gelyke voet naas mekaar te handhaaf' (Pelser 1988:389). Op grond van die kerklike praktyk met sy ideologiese seleksie van bepaalde komponente, of die hoër skatting van sommige dele bo ander, en op grond van die inherente pluraliteit van die Bybel, is dit vir hom duidelik dat 'n mens nie anders kan as om met 'n kanon in die kanon te werk nie.

Die kerk het deur kanonvorming die verskeidenheid hermeneutiese pogings om die Jesus-saak te verstaan, sowel as die ontwikkelings in sommige van hierdie pogings, in 'n formele omgrensing gaan vasvang. Gedurende die eerste vier eeue was daar geen normatiewe vorm van die Christendom nie. Daar was “... nie altyd volkome duidelikheid oor normatiwiteit of kanonisiteit in die vroeë kerk ..."(Pelser 1989:393) nie. Dit is 
vir hom dus noodsaaklik om die normatiewe komponent wat in die pluriforme kanon ontbreek, te identifiseer. Hy noem daardie normatiewe komponent “... die saak ..." (Pelser 1989:394) wat in die Nuwe Testamentiese kanon vervat is. Te midde van die pluriformiteit van die kanon wend hy hom dus in teorie tot 'n monistiese interne saak in die Nuwe Testament wat volgens hom die kernsaak is en wat aan sy definisie van die begrip "kanon" voldoen.

Alhoewel daar op verskillende maniere na die "Sachmitte" in die kanon gesoek kan word, beperk Pelser hom tot 'n paar moontlikhede binne die kategorie van interne gestaltes. Hy werk met 'n hermeneutiese sirkelbeweging waar die kriterium aan die Nuwe Testament self ontleen word en dan weer gebruik word om die Nuwe Testament krities aan te toets. Hoewel daar 'n bepaalde keuse vir 'n kernsaak gemaak moet word, dui Pelser nie enige bepaalde van sy eie aan nie. Hy wys daarop dat daar nooit 'n absolute keuse gemaak kan word nie, omdat daar 'n voortdurende verskuiwing by die hermeneutiese vooronderstellings en kenteorieë van die teoloog plaasvind. Dit is tewens noodsaaklik dat die kanon-in-die-kanon benadering op die pad vorentoe steeds gevolg sal word, omdat dit op dinamiese wyse kreatiewe teologie binne ' $n$ intersubjektiewe dialoog sal stimuleer en steeds gelowiges daartoe sal lei om in 'n eksistensiële ontmoeting met die saak of sake van die Bybel te tree.

Beoordelend en samevattend moet ons dus sê dat Pelser die pluriformiteit van die kanon bevestig. Sy bepaalde definisie van kanonisiteit laat egter nie ruimte vir pluriformiteit nie. In plaas daarvan om met die pluriformiteit te worstel en 'n herdefinisie van sy kanonbegrip te oorweeg, sien hy in die pluriformiteit juis die toelating en die noodsaak om te selekteer en 'n kanon binne die kanon daar te stel. Pluriformiteit word dus hier die motivering en sanksionering om met 'n kanon in die kanon te werk. Terwyl hierdie soort kanonopvatting in essensie modernisties is en vanuit 'n hegemoniese en positivistiese hoek werk asof so 'n kernkanon gevind kan word, is hy egter vir die uitoefen van 'n keuse postmodernisties georiënteerd. Hy wil nie 'n bepaalde keuse uitoefen nie en hy waarsku om al te gemaklik tot 'n finale antwoord te kom. Hy is oorbewus van die onmoontlikheid om die probleem monisties op te los. 


\section{3. 'N OORGANGSTYDPERK}

In sy positivistiese aandrang enersyds op ' $n$ kernkanon, maar andersyds die erkenning dat daar in die kontekstuele netwerk van die leser ' $n$ voortdurende kaleidoskopiese wisseling van intersubjektiewe posisies aan die gang is, plaas Pelser homself op die oorgangslyn van die moderne na die postmoderne. As kind van sy tyd reflekteer sy benadering die beweging in die hedendaagse teologie weg van 'n hegemoniese paradigma na 'n netwerk van immer veranderende posisies. Die fokuspunt skuif weg van die teks af na die interaktiewe terrein tussen teks en leser en die aktiewe en skeppende rol wat die leser van die teks in die leesproses speel. Hierdie skuif na die intersubjektiewe terrein tussen teks en leser gaan gepaard met ' $n$ verandering in epistemologie binne die geloofsgemeenskap. Vanuit die toenemend postmoderne pluralistiese gemeenskap word gesoek na waardes wat werk, nie na waarhede wat absoluut is nie. Die konteks bepaal telkens wat werk en wat waar is. Die Bybel is kanon, nie omdat dit ewige waarhede bevat nie, maar omdat dit in die ontmoetingsgebeure as betroubaar ervaar word. Juis in die eksistensiële ontmoeting met die saak (die Sache) wat die kanon fasiliteer, word sy kanonieke funksie voltrek.

Terwyl Pelser dus postmodernisties oor die funksionering van 'n kanon dink, hoort sy definisie van ' $\mathrm{n}$ kanon by die moderne. Die pluriformiteit word in sy benadering in wese opgehef. Iets wat pluriform is, voldoen nie aan sy verwagting van wat 'n kanon is nie. Die pluriforme kerklike kanon word daarom deur die keuse wat telkens gemaak moet word, gereduseer tot 'n monistiese kanon. Dit gebeur weliswaar binne die hermeneutiese sirkel, maar dit kom telkens neer op 'n ander kanon as die tradisionele kerklike kanon. Dit word 'n ontmoetingsgebeure met die kanon van die leser se eie keuse, nie die pluriforme kanon van die kerk nie. Sy kanon-in-die-kanon benadering akkommodeer nie die vraagstuk van 'n gegewe pluriforme kanon nie. Dit beantwoord nie die vraag van, byvoorbeeld, drie sinoptiese evangelies binne een kerklike kanon nie.

In meer postmoderne georiënteerde benaderings word die vraagstuk van pluriformiteit juis op die voorgrond gestel. Brueggemann (1997), byvoorbeeld, handhaaf die pluralisme van die kanon en probeer 'n leesstrategie aan die hand daarvan ontwerp. In sy motivering hoekom daar opnuut na ' $n$ teologie van die Ou Testament gekyk moet word, wys hy op die "multilayered pluralism" (Brueggemann 1997:xv) in die Bybelse navorsing. Hierdie gelaagde pluralisme manifesteer volgens hom op drie vlakke. Eerstens is 


\section{Kanon in die kanon}

daar in die Bybelteks self 'n pluralisme van geloofsgetuienisse aanwesig. Tweedens is die hegemoniese posisie van die histories-kritiese metodes vervang deur 'n pluralisme van metodes waarmee die teks uitgelê word. Derdens is daar 'n pluralisme van gemeenskappe wat die teks kontekstueel binne hulle bepaalde epistemologie en bepaalde sosio-ekonomiese en politieke belange gebruik.

Waar Pelser hierdie pluralisme aangryp as legitimering vir die gebruik van 'n kanon-in-die-kanon soos hy dit verstaan, sien Brueggemann dit as onmoontlik om terug te keer na 'n tipe hegemoniese positivistiese benadering wat die pluralisme negeer. Binne die toenemend postmoderne gemeenskap is daar vir hom

... no going back to a singular coherent faith articulation in the text (much as canonical approaches might insist on it), no going back to agreed-on critical methods that can maintain hegemony, and no going back to a dominant interpretive community that imagines itself to be immune to contextualideological shaping and interest (Brueggemann1997:xvi). (Ek beklemtoon hier sy verwysing na kanon benaderings met vetdruk)

Die gedagte van 'n kanon-in-die-kanon sal volledig geherdefinieer moet word om hierdie pluriformiteit te akkommodeer. Daar sal binne die konteks van 'n pluriforme gemeenskap, waar die Bybelteks met sy inherente pluriformiteit as kanon funksioneer, na 'n beskrywing gesoek moet word van dit wat teologies normatief aan die werk is in die ontmoetingsgebeure met die teks. 'n Leidraad hiervoor sal op die gebied van die kanonnavoring met al sy nuwer ontwikkelinge gesoek moet word.

\section{KANONNAVORSING}

' $n$ Kanon is tradisioneel gedefinieer in terme van 'n afgebakende versameling van tekste. In die kanonnavorsing het die klem egter weggeskuif van 'n finale versameling van tekste na 'n veel breër sosio-kulturele terrein waarin kanonieke tekste 'n kleiner onderdeel is van 'n veel groter en omvattender proses (vgl Venter 1998). 
In tekskritiese navorsing van onder andere die Dooie Seerolle het dit duidelik geword dat kanonieke gesag nie aan die bepaalde omvang van 'n kanon geheg kan word nie. Daar was meer as een vorm van die kanon in omloop. Waarmee ons te doen het is 'n Rabbyns-Masoretiese teks wat deur die Masorete tekstueel gestabiliseer is oor die loop van die eerste millennium van ons jaartelling. Hierdie kanon is egter slegs een kanon wat oorleef het uit die verskillende kanons wat in Joodse kringe oor die eeue gevorm is. Selfs die kanon wat in Protestantse kringe gebruik word, is 'n hubriede vorm van ouer kanonvorms wat self reeds oor 'n lang tydperk uitgekristaliseer het. Dit is sinneloos om in net een van die verskillende kanonvorms wat daar is, na 'n kern te gaan soek asof dit die waarheid is.

Dit het ook duidelik geword dat kanon eerder op 'n lewende geloofstradisie as op 'n teksgeskiedenis dui. Verskillende gemeenskappe het met 'n verskeidenheid van teksvariante gewerk. Deur 'n reeks sosio-historiese omstandighede het die vorm waaraan een bepaalde groep voorkeur gegee het toonaangewend geword en het die ander variasies van die toneel verdwyn. Ook vanuit sosio-ideologiese hoek is dit duidelik dat 'n kanon 'n multidimensionele aangeleentheid is wat op omvattende vlak hanteer moet word. Groepsdinamika, konkurrensie om mag, literariteit en intertekstualiteit, speel almal 'n rol in die bestaan van kanons. Kanon kan nie langer net in terme van die bestaan van 'n afgebakende teks of die blote bestaan van 'n teks, hoe hoog daardie teks ook al aangeslaan word, gedefinieer word nie. Wat wesenlik in die kanon is (kanon-in-die-kanon), omvat baie meer as net 'n seleksie uit die totale versameling. Dit werk ook op 'n baie breër vlak as net literatuur.

Teenoor 'n voormalige neiging tot reduksie, bevorder die navorsing na die kanon dus ' $n$ tendens na die insluiting van al meer en meer faktore in die werking van 'n kanon. Pluriformiteit op elke denkbare vlak vanaf die kanon literatuur tot die gemeenskap wat met die kanon te doen het, word op die voorgrond gestel. Kanon-in-die-kanon kan nie langer met reduksie en met 'n minimum werk nie, maar sal met 'n baie groter omvang moet werk. Dit sal die skuif vanaf ' $n$ teksgesentreerde beskouing na 'n meer omvattende proses moet verdiksonteer. Hierdie noodsaaklike veranderinge word duidelik uit die ontstaan en ontwikkeling van die dissipline wat breedweg as kanonkritiek beskryf kan word. 


\section{KANONKRITIEK}

Kanonkritiek word veral verbind aan die name Brevard S Childs en James A Sanders. Albei van hulle het die teologiese betekenis van die Ou Testament aan die kanonvorm daarvan verbind. Childs het die finale vorm beklemtoon, terwyl Sanders die proses wat daarmee gepaard gaan, beklemtoon het. Uit vorige navorsing (vgl Venter 1998) kan 'n paar riglyne in hulle werk getrek word wat vir die vraag na die kanon-in-die-kanon ter sake is.

\subsection{Childs se siening}

Vir Childs is die teologie van die Bybel te vind in die finale kanonvorm. Die gesaghebbende teologie van die Bybel waarmee die leser in ontmoeting tree, lê binne die totale spanningsveld van àl die boeke van die Bybel. Die swak punt in Childs se redenasie is dat hy nie presies aandui watter een van die verskillende kanons of lyste van boeke hy bedoel nie. Dit is dus ook nie presies duidelik waarop sy Bybelse teologie rus nie. Sy aandrang dat die gehéél van die kanon in berekening gebring moet word, verteenwoordig egter ' $n$ verruiming en beweging na die maksimum. Alles in die Bybel staan vir hom in 'n interafhanklikheid.

Dit word egter problematies wanneer hy aan hierdie teologie wat binne die raamwerk van die finale kanon tot stand gekom het 'n universele waarde toeken wat tydloos relevant is vir elke gemeenskap. Dit is ' $n$ teologie wat los van geskiedenis staan en beperk is tot tekstualiteit. Brueggemann (1997:92) sê dat Childs wesenlik met die “... cognitive and conceptual constants of the faith ..." werk. Hier is 'n absolutistiese beskouing aan die werk wat die teologie van die Bybel sien as iets wat vir eens en altyd gevind kan word mits die geheel van die kanon in gedagte gehou word. Hy sien ook daardie teologie wat in die finale vorm van die kanon vasgevang is, as iets wat nie kanonieke gesag gehad het alvorens die finale kanonvorm nie eers voltrek is nie. Eers van daar af het dit as ' $n$ universele tydlose openbaring gefunksioneer wat voortdurende aktualiteit behou vir elke geloofsgemeenskap daarna (vgl die bespreking van Childs by Brett 1991:76-115). Die finale kanonvorm is vir hom die deursigtige getuienis van 'n universele openbaring daaragter. Die kernsaak is vir hom 'n statiese teologie wat self nie 
weer verander nie, maar dinamies ingaan in die bestaan van elke gemeenskap wat dit gebruik.

By Childs is daar nie 'n intersubjektiewe ontmoeting tussen teks en leser nie, maar 'n eenrigting ontmoeting wat preskriptief aan die leser net een aktiwiteit ooplos en dit is om die gegewe kanon innoverend te implementeer. Die estetiese dimensie van die teks word dus beklemtoon sodat die teks 'n inherente gesag het wat kan funksioneer sonder enige bepaalde geloofsgemeenskap en selfs sonder God. Die teks het vir Childs wat Deist (1988:199) noem 'n “ontologiese status". Hy werk met wat Davies (1998:51) noem 'n "literary icon".

Daar is egter ook 'n teenstrydigheid in sy werk. Hier vind nie 'n reduksie van die kanonomvang plaas nie. Inteendeel, die gehéél van die kanon word betrek. Volgens Brueggemann (1997:92) is Childs se werk egter "massively reductionist". Childs werk nog steeds met 'n kanon-in-die-kanon volgens 'n reduksionistiese beginsel. Dit is 'n universele openbaring wat as kern in die geheel van die kanon teenwoordig is. Dit is ' $n$ monistiese kanon-in-die-kanon wat in 'n formule uitgedruk kan word. Nader gesien is dit die inhoud van die Nuwe Testament wat die kernkanon vorm. Alhoewel die hele kanon betrek word, kom die eintlike kanonieke status vir Childs eers tot stand wanneer die Nuwe Testament op die toneel kom. Die wesenlike pluriformiteit van die kanon word vereng tot die inhoud van die Nuwe Testament. Die universele teologie van die kanon is in feite die teologie van die Nuwe Testament. Sy hele oefening is daarop gerig om sover moontlik die Ou Testament te verbind aan die Nuwe Testament. Selfs die pluriformiteit van die Nuwe Testament word gereduseer tot die kern van 'n finale openbaring.

\subsection{Sanders se siening}

Waar die lokus van kanonieke gesag by Childs geleë is in 'n finale openbaring wat die kern vorm van 'n finale teks, is dit by Sanders geleë in die proses van kanonvorming. Teks en gebeure loop hier saam. Die kanonteks is die outentieke bron van hierdie proses. Meer nog, die kanonteks verskaf die paradigma vir die kanonproses. Dit dui nie net aan hoe daardie proses in die verlede verloop het nie, maar normeer ook die voortgaande kanonproses vir die hede en die toekoms. 
Sanders het met sy begrip canonical criticism die basis gelê vir die bestudering van hierdie proses. Hy noem sy basisteorie die hermeneutics of biblical intertextuality (Sanders 1995:59). As subdissiplines hiervoor gebruik hy wat hy noem comparative midrash en die hermeneutical triangle. Met hierdie hermeneutiese driehoek bedoel hy die manier waarop die tradisie telkens gewerk het tussen die drie ankerpunte van die gebruikte ouer tradisie, die eietydse sosio-politieke situasie en receptor hermeneutics waarvolgens die ouer tradisie hanteer en toepaslik gemaak is. Hierdie tipe hermeneutiek was vir hom basies theocentric en monotheizing. Deur dinamiese analogie is ouer tradisie ò teregwysend òf bemoedigend op so 'n manier op nuwe situasies toegepas dat dit vir die geloofsgemeenskap as kanon kon dien wat hulle met God gekonfronteer het en laat besin het oor wie hulle voor God is en wat hulle vir Hom moet doen.

Hierdie kanonproses was nie net die historiese teelaarde vir die bestaande kanon nie, maar die bestaande kanon verskaf die paradigma vir die voortgang van hierdie proses in elke geloofsgemeenskap. Sanders akkommodeer die pluriformiteit van die kanon deur dit as trajekte in 'n akkummulerende proses te beskou. Dit is nie die vorm wat die kanon tydens een van hierdie trajekte gehad het nie, maar die proses self soos in elke trajek verteenwoordig wat vir hom die sleutel is om daardie vorm te verstaan. Die kanongeskiedenis kan ook help verstaan waar die gegewe kanonvorm vandaan kom. Die probleem is egter dat as dit ' $n$ voortgaande proses is, hoekom bly die kerk dan vashou aan een bepaalde gestalte van kanonvorm uit die een bepaalde fase van die hele proses? Sanders hanteer nie hierdie probleem nie, omdat dit sekondêr staan tot die wesenlike proses waarom dit in kanonisering gaan. Volgens Sanders (1995:62) "... closure did not make that much difference in the ongoing canonical process. Once firm stabilization of text and canon set in, communities found the hermeneutics whereby they continue to render the stable fluid; they continued to need to know who they were and how to live in ever-changing circumstances" (Sanders 1995:62).

Waar Childs alles veranker aan een bepaalde vorm en een bepaalde tyd uit die geskiedenis en daaraan 'n gefikseerde teologie heg, onderspeel Sanders die feit dat daardie bepaalde vorm steeds gehandhaaf word. Hy verplaas die klem totaal weg na 'n proses waarvan die huidige kanonteks referent en tegelyk instigeerder is. Die kernsaak by Childs is ' $n$ idee, ' $n$ finale openbaring soos gedemarkeer in ' $n$ finale Bybelse kanon- 
versameling, geïnterpreteer vanuit die Nuwe Testament. Die kernsaak by Sanders is ' $n$ gebeure, 'n voortgaande kanonproses waarvan die pluriforme kanon sowel produk as toonaangewende bron is. By Childs is dit die traditio wat by die vroeë Christen geloofsgemeenskap in sy gefinaliseerde kanonvorm vasgevang is. By Sanders is dit 'n traditum wat in opeenvolgende geloofsgemeenskappe in proses was en is. Die kanon-in-die-kanon by Childs is ' $n$ konstante, terwyl dit by Sanders ' $n$ veranderlike is. Childs se teologiese kern vind in geloofsgemeenskappe telkens ander toepassingsmoontlikhede sonder dat die kern daarvan verander. Sanders se teologiese proses vertoon in verskillende geloofsgemeenskappe ' $n$ innoverende dinamiese beweging te midde van akkummulerende kontinuïteit. By albei is daar 'n beginsel van kanon-in-die kanon aanwesig, maar 'n radikale verskil in hulle definisie van kanon. Childs werk met 'n meer modernisties verabsoluteerde opvatting en Sanders met 'n meer postmodernisties georiënteerde intersubjektiewe en dinamiese opvatting.

By albei navorsers is daar ' $n$ tendens tot redusering. Childs se reduksie is verabsoluterend en ideematig. Sanders se reduksie is sentrifugaal en dinamies. Sanders se opvatting het 'n beter kans om die pluriformiteit van die kanon en die intersubjektiewe ontmoeting tussen teks en leser te akkommodeer as die van Childs. Sy beskrywing van die proses is egter vaag en neig sterk na veralgemening. Hierop sou die verdere navorsing kon ingaan.

\section{DIE KANONPROSES}

Die kanonbegrip het dus begin wegskuif van die tekstuele alleen. ${ }^{1}$ Die kanon-in-diekanon is nie langer net ' $n$ seleksie uit die totale literatuurversameling van die kanon, of ' $n$ bepaalde verabsoluteerde (dogmatiese) skema of 'n bepaalde konstante teorie nie, maar die aanduiding van 'n hele proses waarin die literêre maar slegs een komponent is. Teenoor 'n deduktiewe benadering het 'n verruimende tendens gekom wat die proses in sy volle omvang bestudeer. Kanon word nie meer atomisties verstaan nie, maar in terme van ' $n$ hele aantal konstituente. Dit is ' $n$ multidimensionele aangeleentheid wat op inter-

\footnotetext{
1 Die gedagte van sola Scriptura word nie daarmee laat vaar nie. Die definisie word verander sodat dit nou die Skrif-in-konteks word en die Skrif ' $n$ lewende tradisie waarvan die skriftelike neerslag een komponent is.
} 


\section{Kanon in die kanon}

dissiplinêre en omvattende vlak nagevors word. Definiëring van die kanon en van kanonisiteit word gesien binne die totale proses “... waarin mense in hulle oneindige pluriformiteit op hoeveel wyses met die almagtige God gekonfronteer word en deur sy almag bemagtig word om vanuit hulle konkrete situasie voor en met Hom te lewe" (Venter 1998:77).

Die kanon funksioneer binne die raamwerk van die “... historiese bewussyn, die kontekstualiteit en intertekstualiteit van tekste, meesternarratiewe en kontravertellings, en belangegroepe agter kanonisering" (Breytenbach 1997:1168). Dit wat wesenlik in die kanonproses aan die gang is lê nie net vasgevang in die literêre teks, die aard of vorm van die kanon nie, "... but in the context in which it is interpreted and, therefore, in the special set of intertexts of which it forms part. These intertexts include power relations, views of authority, specific beliefs and religious traditions, particular textual theories and methodologies with their implied interpretive strategies, readers' expectations, and so forth" (Deist 1995:78).

Davies (1998) het hierdie sosiale dimensie van die proses breër uitgewerk. Hy sluit hom by Sanders aan in die siening dat dit eerder om 'n proses gaan as net blote literatuur. Soos Sanders dink hy ook dat die proses bly voortgaan selfs nadat 'n kanon finaal afgesluit is. Linguistiese en kulturele veranderings, kommentare en vertalings vereis dat 'n kanon onbepaald bly voortgaan. Davies (1998:12) sê: "The fluidity of the canonizing process is transformed by a fixed canon into a fluid hermeneutical process ..." Davies het waardering daarvoor dat Sanders die kontinuïteit in die proses raaksien, die verbinding tussen kanonvorming en kanonontvangs hanteer en die ideologiese pluraliteit van die gekanoniseerde geskrifte beklemtoon. Hy het egter probleme met Sanders sowel as Childs wat met hulle kanonkritiek op die vlak van die geskiedenis beweeg, maar in wese eintlik met teologie besig is. Hulle beklemtoon wel die rol van die geloofsgemeenskap, maar dit is waar hulle belangstelling in die historiese produksie van die kanon gewoonlik ook ophou. Hoewel die gedagte van kanons as gemeenskapsprodukte vir hulle belowend lyk, is dit egter net vir hulle van belang in soverre as die gemeenskappe voorlopers van die Christelike gemeenskap is. Hulle kanonkritiek is in der waarheid onhistories - in praktyk by Sanders en in beginsel by Childs, wat weier om die historiese proses te ondersoek waardeur literatuur kanon geword het. Die konsep van die 
kanonproses is egter baie bruikbaar indien die historiese en sosiologiese aspek daarvan ook by die ondersoek betrek word. Davies (1998:41) meen dat "Too little work has been done on the sociology of Jewish canonizing".

Davies se werk gaan eerder oor die prosesse waarin kanons ontwikkel word as oor kanons self. Hy bestudeer die sosiale faktore in die geskiedenis van die Israelse en Judese gemeenskap wat in kanonisering 'n rol speel. Hy neem ook die verloop van kanonprosesse in ag soos dit in Mesopotamië, Egipte en die Griekse en Hellenistiese wêrelde voorkom. Die gekanoniseerde weergawe van Israel se eie geskiedenis is volgens hom deurspek met die rol wat gekanoniseerde uitsprake daarin gespeel het: "The rabbinicMassoretic canon, then, is itself full of allusions to canons and reflects a mentality in which they are regarded as central to the political and religious government of the Jews" (Davies 1998:56). Davies (1998:56) vind oral die aanduiding van 'n "canonical process" of "canonical consciousness". Dit kom voor in die manier waarop literatuur hanteer word, waarop sosiale instellings georden word, waarop leiers van die volk gesien word en die geskiedenis beskryf word. Hy kry dit in gekanoniseerde instellings soos die dinastie van Dawid, die priesterdom en ander sosiale instellings in Israel. Dit kom ook literêr voor binne die Psalms waar kleiner kanonversamelings aan Dawid toegeskryf word, al kom nie al die materiaal van hom nie. Die Spreuke versameling word aan Salomo toegedig al kom daar binne in kleiner versamelings voor wat aan ander persone soos Hiskia, Agur en Lemuel toegeskryf word. Hieruit is dit vir hom duidelik dat die produksie en ontvangs van kanons met veel meer te doen het as net literatuurvorming. Dit slaan op 'n veel breër gemeenskap as net die groepe wat kanons geskryf en geskep het. As menslike produkte vereis kanons ook studie van menslike, dit wil sê sosiale prosesse.

Die kanonproses sluit verskillende fases in vanaf komposisie, oorlewering van materiaal, seleksie, redigering, argivering, die bymekaarsit van boekrolle tot die uiteindelike vorming van formele lyste. As neweproduk van 'n bewustelik literêre kultuur bestaan kanonisering nie net uit invoeging in 'n lys nie, maar uit kopiëring en argivering. "A work does not become canonized by being included in a formal list. A work becomes canonized (a) by being preserved by copying until its status as a classic is ensured; and (b) by being classified as belonging to a collection of some kind" (Davies 1998:9). Dit is 
nie eers in die finale fase dat kanonisiteit ter sprake kom nie. "Canonical does not imply only a fixed status in a list but can reflect a number of degrees of 'canonization' prior to that" (Davies 1998:58). Dit is ook nie 'n eenvormige proses waar alle materiaal op dieselfde stadium van die proses is nie: “... there is no single canonical mechanism or 'trajectory'. There are 'canonical processes', however, and they operate within the formation of scrolls as well as in the grouping of scrolls" (Davies 1998:58).

Om die kanonproses te verstaan wat vanaf komposisie deur redaksie tot finale gefikseerde en gekanoniseerde tekste gelei het, is oop vir "a bewildering range of explanations" (Davies 1998:42). 'n Wye verskeidenheid tegnieke is gebruik met net soveel redes en oorwegings. Volgens Davies (1998:53) is daar "... signs of editing ('shaping') of the scriptural literature that point to some integration between various works." In die oordrag van boekrolle is een of ander poging aangewend om hulle met mekaar te verbind, of deur hulle kronologies te orden, of deur toespeling van tekste. Daar was “... an ongoing process by means of which canonized writings are to some extent brought together by the provision of cross-references, chronological arrangements, superscriptions, and intertextual allusions" (Davies 1998:44). Tekste is nie totaal los van mekaar oorgelewer nie, maar is as deel van 'n groter korpus beskou. Die samestelling van 'n lys van boeke was 'n latere uitvloeisel van hierdie proses. Die outeurskap van 'n enkele boek of reeks van boeke kan eenvoudig wees om te verklaar. Dit is egter iets anders om te verklaar hoekom daardie boeke oorgelewer is. Die kohesie tussen 'n groep gekanoniseerde boeke kan deur 'n enkel outeurskap verklaar word, of selfs uitgebrei word tot kollektiewe outeurskap wat deur volgehoue vormgewing dit in 'n finale vorm gegiet het. Daar is 'n legio van verskillende verklaringsmoontlikhede vir wat in hierdie proses gebeur het.

Die saak word nog meer ingewikkeld wanneer die sosiale dimensie in berekening gebring word. Vir hierdie oordrag, vorming, seleksie en oordrag van materiaal moet “... scribal institutions and practices by means of which literature is both formed and become classics" (Davies 1998:48) in gedagte gehou word. Kanonisering is per slot van sake tog ook 'n sosiale proses. Die groeiende kanonmateriaal “... were selected by a process of copying, studying, teaching, or whatever, by the scribal institutions that preserved literary 
culture, before being accorded the definitive status they finally received from the rabbis" (Davies 1998:48).

In die geskiedenis van die navorsing na kanonvorming is al verskillende teorieë ontwerp om hierdie ingewikkelde proses te verklaar. Die finale kanonvorm met sy wye verskeidenheid materiaal is al verklaar vanuit kompromieë wat tussen partye getref is (Brettler), versoening tussen partye wat tot 'n program van nasionale eenheid in kanonvorming gelei het (Miller) en konsensus in die rabbynse beweging (Carr). Davies se probleem met hierdie verklarings is dat elkeen met ' $n$ beslissende en finale gebeure van kanonvorming werk, in plaas daarvan om dit as 'n deurlopende proses te sien wat in elke fase dieselfde eienskappe vertoon. Boonop stem hierdie teorieë nie ooreen oor die tyd in die geskiedenis wanneer die finalisering dan sou plaasgevind het nie. Daar is ook verskille in die teorieë oor die tipes gemeenskappe en verskillende besluitnemers wat aan die proses deelgeneem het.

Terwyl Davies van 'n deurlopende proses praat, maak hy egter 'n keuse vir een aspek daarvan wat vir hom die belangrikste is. Hier het ons Davies se kanon-in-diekanon. Hoewel kanon vir hom 'n ingewikkelde proses is met 'n byna onoorsigtelike aantal konstituente, is daar tog iets wat vir hom in die kern van die saak lê. Dit lê vir Davies (1998:44) by daardie fase waarin "canonized writings are ... brought together." Hy verklaar: "It is here, rather than in the process of either writing or list compiling, that the heart of the canonizing process is located" (Davies 1998:44). Hy beklemtoon wat hy vroeër gesê het: “.... these processes of discrimination and of formal selection constitute the core of the 'canonizing process"'(Davies 1998:10). Die wesenlike van 'n kanon is vir hom die keuse wat uitgeoefen word in bestaande materiaal en die samevoeging daarvan in 'n kombinasie. Soos die resepsieteorie die idee verskuif het dat die teks 'n inherente en onveranderlike betekenis het na betekenistoekenning wat eers tydens die proses van lees plaasvind, lê die wesenlike van 'n kanon in die betekenis wat op die stadium van seleksie en samevoeging toegeken word.

Daarmee saam gaan natuurlik die vraag wie dit is wat hierdie seleksie en bymekaarsit onderneem. Wie is dit wie se koppe so werk dat jy moet selekteer en bymekaarsit om iets kanonieks deur te gee? Dit was die leiers en nie die gemeenskappe self wat die kanonproses bepaal het nie. Sosiaalwetenskaplike navorsing wys uit dat hierdie kanons 
nie algemene tradisies is nie, maar die produk is van die elite: "The scriptural canon cannot and does not represent an amorphous 'Israel' but a set of elitist portraits" (Davies 1998:41) ${ }^{2}$. Godsdienstige kanons is nie die produk van die aanhangers van 'n godsdiens nie, maar van hulle wat hulleself as die leiers aanbied. "All canonizing is elitist in conception and authoritarian in implementation" (Davies 1998:10). Kanons bly steeds 'n meganisme van beheer: "In Foucaldian terms, a canon itself should be seen as a locus of power, facilitating cultural hegemony" (Davies 1998:11).

Die aspek van verskeidenheid in dit wat deur seleksie bymekaargesit is, hanteer Davies op 'n teleurstellende manier. Hy val hierin maar weer terug op 'n verouderde vorm van die kanon-in-die-kanon siening. Hy erken wel "that canons, notional or inscribed, are not unilayered" (Davies 1998:11). Sy verklaring is egter dat sommige werke meer kanoniek is as ander, soos byvoorbeeld in die skriftelike RabbynsMasoretiese kanon waar die Tora-gedeelte hoër gesag as die res van die kanon geniet. Soms word na die Tora verwys as die kanon. Davies (1998:12) voer verder aan: "In the Christian scriptures, the New Testament is in similar sense more 'canonical' than the Old, providing the key to its 'correct' understanding, abrogating many of its statements." Dat 'n kanon dus onderskei tussen dit wat gesag het en nie gesag het nie, is slegs tot op bepaalde hoogte waar: "neither within or outside canonical boundaries is there equality. Canons do not grow up with rigid boundaries, and the creation of such boundaries does not eliminate gray areas either within ('law' versus 'gospel', 'torah' versus 'prophets') or on the edges (the 'apocrypha') of the canon" (Davies 1998:12).

Met hierdie siening val hy terug op 'n literêre benadering wat literatuur teen literatuur afspeel. Die een deel word met die sleutel van die ander deel gelees. Dit verklaar nie hoekom daar in die proses keuses uitgeoefen is wat selfs teenstellende materiaal kies en met mekaar kombineer nie. Hy vereng kanongesag monisties tot literêre kerns sonder om die moontlikheid oop te laat dat daar 'n eiesoortige denke in die Bybelse kanonvorming aanwesig was wat bipolêr kon dink. Vir hierdie beredenering moet ons by Brueggemann se teologie van die Ou Testament van 1997 uitkom.

\footnotetext{
2 Hiermee saam hang Davies se grondtese dat Israel nie die kanon gemaak het nie, maar dat die kanon Israel gemaak het. Hy bespreek hierdie stelling egter nie uitvoerig in die bepaalde werk nie.
} 


\section{BRUEGgEMANN SE HANTERING VAN DIE PLURIFORMI- TEIT IN DIE OU TESTAMENT.}

Brueggemann (1997) beskryf die teologie van die Ou Testament. Alhoewel hy soms na die kanongestalte daarvan verwys, speel die kanonisiteit van die Ou Testament nie by hom die hermeneutiese rol wat dit by Childs en Sanders speel wanneer hulle die teologie daarvan probeer bepaal nie. Brueggemann wil eerder met die eie aard en inherente logika van die teks werk en daarvolgens bepaal wat die teologie van die Ou Testament is. Omdat hy nie met kanonkritiek werk nie, definieer hy ook nie sy teologie in terme van die nosie van kanon nie. Die teologie wat hy egter beskryf en aanbied as die wese van die Ou Testament, is direk ter sake vir 'n kanon-in-die-kanon beskouing wat wel in terme van die nosie van die kanon werk. Dit gee rigting aan die vraagstuk van die pluriformiteit van die Ou Testamentiese kanon.

Brueggemann beskou sy postliberale lees van die teks van die Ou Testament as “... an attempt to exposit the theological perspectives and claims of the text itself, in all its odd particularity, without any attempt to accommodate to a larger rationality, either of modernity or of classical Christianity" (Brueggemann 1997:86). Dit gaan oor wat hy beskou as die eiesoortige interne logika van die teks en die bepaalde grammatika en dialektiek van die tekstuele tradisie daarin. Hy lees dit teen die agtergrond van die veranderings, transformasies en aanpassings wat Israel deur sy geskiedenis ondergaan het.

Die bepaalde retoriese styl van die Ou Testament en die Joodse denkpatroon word in die klassieke Westerse teologiese gesprek gewoonlik vereng en volgens Aristoteliese logika vrygemaak van alle teenstrydighede of dubbelsinnighede. Dit laat nie reg geskied aan die inhoud van die Ou Testament nie: "Indeed, to read the Old Testament in order to articulate ordered, cognitive constancies in the text is likely to read against the character of the text itself" (Brueggemann 1997:83). Die uitgangspunt van sy werk is dat "the Old Testament in its theological articulation is characteristically dialectical and dialogical, and not trancendentalist" (Brueggemann 1997:83).

Dit is belangrik om hierdie dialektiek in die teks raak te sien in die huidige pluriforme gemeenskap. Dit is ' $n$ wesenlike kenmerk van die resente pluriforme gemeenskap dat daar 'n veelvoud van opinies is. Om hierdie konflikterende opset te hanteer moet teruggegaan word na die teks waarin daar 'n soortgelyke konflikterende pluriformiteit is. "We 


\section{Kanon in die kanon}

now have rival accounts or construals of Old Testament theology, of which the most visible alternatives appear to be canonical, liberationist in its several submodels, and historicalcritical, which tends to yield a minimalist or skeptical account of the matter" (Brueggemann 1997:62). Om uit hierdie impasse te kom is 'n heeltemal ander soort Ou Testament teologie nodig:

Old Testament theology does not aim at the outcome of a system of settled propositions. Rather Old Testament theology, understood in these categories is an attempt to engage this life-in-rhetoric, which has no logical beginning or end and no rational shape judged by more discursive rhetorics. Therefore, in identifying the characteristic accents and themes, one may begin anywhere and notice a kind of coherence in which all themes are held in relation to all others. In such a discernment, one is not likely to complete a system of theology, but only to observe and participate for a while in the practice of this rhetorical activity, whereby the whole of reality is received and appropriated differently. This means, in the end, that theological interpretation is a modest enterprise that always, inevitably, must leave much unsaid and perhaps even unnoticed.

(Brueggemann 1997:80)

In hierdie situasie is daar dus geen finale antwoorde nie. Daar is 'n voortdurende gesprek aan die gang waarin daar by herhaling beslissings gemaak moet word en standpunt ingeneem word. Dit is 'n voortgaande proses wat in die aard van die Bybelteks self veranker is. Elke antwoord is ook dienstig aan 'n bepaalde belang. "We now recognize that there is no interest-free interpretation, no interpretation that is not in the service of some interest and in some sense advocacy" (Brueggemann 1997:63). In hierdie konflik is dit volgens Brueggemann (1997:63) nodig "to stay engaged in such an adjudicating process." Teologiese interpretasie as voortgaande beslissing is volgens sy tese getrou aan die aard van die teks self.

Brueggemann (1997:74) vind 'n "revolutionary propensity in the text". Daar is aanduiding van voortdurende beslissings wat geneem moes word met gevolglike pleitbesorging van die bepaalde standpunt waarvoor gekies is. Saam met Rainer Albertz sien hy die geskiedenis van die godsdiens van Israel en dus ook hulle tekste as "incessantly 
pluralistic" (Brueggemann 1997:64). Dit spruit voort uit die proses van herhaaldelike posisionering. "Albertz, moreover, concludes that the canon itself is a compromise, in which no party to the adjudication is silenced or driven from the field, meaning from the text, and no party completely dominates" (Bruegemann 1997:64). Die kanon getuig dus van 'n pluralisme wat in die spanningsveld van teenoorstaande standpunte staan. Wat tot dusver in die navorsing as redaksie of redigering gesien is, is in der waarheid deel van 'n voortgaande proses (“ongoing work of adjudication" - Brueggemann 1997:64) waarin beslissing geneem is, onderhewig aan voortdurende hersiening. Die pluralisme van die teks lê in die spanning van hierdie verskillende aanbiedings van die waarheid en "no amount of historical criticism or canonical interpretation" (Brueggemann 1997:64) kan dit reduseer tot 'n enkelvoudige antwoord nie.

Dit is veral die omstandighede van die ballingskap wat die godsdiens van Israel in hierdie rigting laat beweeg het. Ouer materiaal is in daardie tyd gebruik en "the exilic and/or postexilic location of the final form of the text suggests that the Old Testament materials, understood normatively, are to be taken precisely in an acute crisis of displacement, when old certitudes - sociopolitical as well as theological - had failed." (Brueggemann 1997:75). Wanneer al die ander instellings waarop daar vir lank gereken was, ineenstort, word dit die teks wat deur hergebruik die koers aangee. Die ouer materiaal is op ' $n$ verbeeldingryke manier gebruik sodat sowel kontinuïteit in die vroeëre lokaliteit daarvan bewaar gebly het, maar tegelyk diskontinuitteit ingebou is omdat die teks in die krisis van die ballingskap opnuut gebruik is. Teenstellende pluriformiteit word sodoende ' $n$ kenmerk van die teks in wording. Die teks word so ingespan "to state competing claims" (Brueggemann 1997:64).

In die "adjudicating pluralism of the Old Testament" (Brueggemann 1997:65) is daar nie plek vir 'n hegemoniese of essensialistiese uitspraak wat ander uitsprake van die tafel vee nie. Daar is geen reglynige ontwikkeling van Israel se geloof nie. Elke voortgang van die dialekties-dialogies teologiese gesprek was 'n worsteling en maar net 'n posisionering vir 'n volgende worsteling. Juis die manier waarop God verwoord word in hierdie teenstellende waarheidsaansprake stel egter retories die eie aard van God daar. Juis in hierdie bepaalde soort retoriek is die God van die Ou Testament aanwesig. God is binne die moment van die retoriek altyd opgeneem in 'n voortgaande oop gesprek. Sy teodisee word 
nooit finaal uitgewerk nie. Dit is Brueggemann (1997:66) se oortuiging “... that the God of Old Testament theology as such lives in, with, and under the rhetorical enterprise of this text, and nowhere else and in no other way."

Die pluralisme van geloofsgetuienisse in die Bybelteks self, die pluralisme van metodes waarmee die teks uitgelê word en die pluralisme van gemeenskappe wat die teks geskep het, dui vir Brueggemann aan dat daar eerder as op tematiese sake op die "processes, procedures, and interactionist potential" (Brueggemann 1997:xvi) van die gemeenskap gefokus moet word. In die geloofsgemeenskap gaan dit wel gemeenskaplik oor uitsprake oor Jahwe, maar dit word gekenmerk aan variasie, teenstelling en selfs konflik. In 'n interpretatiewe konteks wat aandag gee aan "pluralism in every dimension of the interpretative process" (Brueggemann 1997:xvi) word die interaksie tussen geloofsuitsprake juis gesien as dit wat openbaring daarstel en waarheid beliggaam. Israel se aansprake op die waarheid werk juis deur ' $n$ proses van interaksie van getuienis en teen-getuienis. Dit is juis die meervoud van stemme wat saam die teologiese inhoud van die Ou-Testamentiese teologie uitmaak. Hierdie proses van getuienis en teen-getuienis is kongruent aan die pluralisme in die teks, interpretasiemetodes en vertolkende gemeenskappe.

\section{KONKLUSIE}

Wanneer die nosie van kanon gebruik word om die waarheidsaansprake van die Bybel te verwoord, word daar dikwels gewerk met die gedagte van 'n kanon-in-die-kanon. Die aanwending van hierdie gedagte hang uiteraard saam met die definisie van die nosie van kanon wat gebruik word.

In hierdie artikel het ons aangetoon dat daar 'n beweging aan die gang is weg van die tekstuele na die groter konteks van die sosiale wêreld waarin kanons funksióneer. Dit is nie net die eindvorm van die kanonteks nie, maar die hele proses waarin kanons gevorm is en waarin hulle gebruik word, wat ter sprake kom. Die neiging tot die gebruik van 'n kanon-in-die-kanon lyk of dit steeds aanwesig bly. Dit is egter nie langer houdbaar om dit deduktief of net in die sin van 'n literêre konstruk te gebruik nie. Dit het saam met die herdefinisie van kanon verskuif na die verwikkelde gebruik van kanons in die gemeenskap. 
Davies se kanon-in-die-kanon, wat dit aandui as 'n proses van seleksie en bymekaarsit, bied 'n lewensvatbare moontlikheid. Wanneer die teks gelees word as die weergawe van ' $n$ lewende proses, met alles wat daarin 'n rol gespeel het en die leser speel daarop in met sy/haar volle kontekstuele belading, kan dit sin en inhoud gee aan 'n ontmoeting met die God van wie die Bybel getuig. Die tendens sal nie deduktief wees nie, maar juis verruimend.

Brueggemann se "adjudicating"-benadering open twee verdere moontlikhede. Die eerste is dat dit nie ' $n$ verstarde proses is nie, maar ' $n$ proses wat steeds aan die beweeg is. Davies se seleksie en bymekaarsit is iets wat weer en weer gedoen moet word. Met elke nuwe rolspeler wat bykom en elke nuwe situasie wat opduik, moet daar hergroeper en opnuut besin word oor die posisie wat ingeneem en verdedig moet word. Die oomblik dat 'n kerk of persoon in 'n statiese posisie vasval, word sy/haar kanon gedekanoniseer deur die nuwer verwikkelinge. Die nomadiese reis kom nooit tot 'n einde nie, maar word oneindig voortgesit.

Die tweede moontlikheid wat Brueggemann open, is dat hierdie herposisionering nie maar net 'n rondspring van een keuse na 'n ander is nie, maar 'n rangskikking en herrangskikking van selfs die mees teenstrydige komponente van die kanon. Dit is die kanonteks juis in sy kontrasterende pluriformiteit wat langs 'n ryk verskeidenheid van metodiese kanale teologiese waarde bied aan 'n ryklik geskakeerde samelewing. Die kanon-in-die-kanon (in terme van kanonisiteit gesien), of teologie van die Bybel, lê dan nie vasgevang in een absolute of verengde stelsel nie, maar funksioneer vitaal in 'n voortdurende ontmoeting tussen God en mens in 'n onoorsigtelike variasie van moontlikhede en geleenthede.

\section{Literatuurverwysings}

Brett, MG 1991. Biblical criticism in crisis? The impact of the canonical approach on Old Testament studies. Cambridge: Cambridge University Press.

Breytenbach, A P B 1997. Meesternarratiewe, kontranarratiewe en kanonisering - 'n perspektief op sommige profetiese geskrifte. HTS 53(4),1161-1186.

Brueggemann, W 1997. Theology of the Old Testament. Testimony, dispute, advocacy. Minneapolis: Fortress Press. 
Davies, P R 1998. Scribes and Schools: The canoniztion of the Hebrew scriptures. Louisville, Kentucky: Westminster John Knox Press.

Deist, F E 1988. Witnesses to the Old Testament: Introducing Old Testament textual criticism. Pretoria: NGKB.

- 1995. Canonical literature: Some ideology-critical observations. Acta Academica Supplementum 1, 66-80.

Pelser, G M M 1989. Die kanon in die kanon as hermeneuties-teologiese probleem. HTS 44(2), 388-403.

Sanders, J A 1995. Scripture as canon for post-modern times. Biblical Theology Bulletin 25(2), 56-63.

Venter, P M 1998. Wat beteken "kanon" vandag? HTS 54(3\&4), 505-528 